\title{
Basic Steps to Creating a Conservation Land Trust in Florida'
}

\author{
Benjamin W. North, Elizabeth Frances Pienaar, and Jessica D. Sullivan ${ }^{2}$
}

\section{Why create a conservation land trust for your community?}

Conservation land trusts, more commonly called land trusts, are private 501(c)3 nonprofit organizations that protect land important to your community or region for its natural, cultural, and recreational value.

The state of Florida currently has 25 active land trusts. There is an opportunity to create more land trusts throughout Florida's municipalities, counties, and regions. Below, we briefly describe the role of land trusts and then discuss basic steps to creating a land trust in your community.

\section{The role of a land trust}

Land trusts protect land to provide direct and indirect public benefits such as water filtration and storage, aquifer recharge, food, fiber, lumber, clean air, recreation, scenic views, preservation of historic and cultural resources, and protection from natural disasters, such as floods and droughts (Land Trust Alliance, 2018).

Land trusts can have diverse roles in supporting land conservation. Land trusts can protect land by owning it directly (known as fee land) or through a conservation easement on land owned by another individual or entity. Conservation easements are legal agreements that permanently protect the conservation values of the land by limiting future development. For more information on conservation easements, please see Conservation Easements: Options for Preserving Current Land Uses: http://edis.ifas.ufl.edu/fr149.

Other ways land trusts can support land conservation include providing technical and financial assistance to landowners, supporting regional conservation efforts through partnerships with other organizations (e.g., protecting wildlife corridors), and providing education programs and events related to conservation. For more information on the basic functions of land trusts please see Land Trusts in Florida: A Brief Guide to Land Trusts to Protect Land in Your Community: http://edis.ifas.ufl.edu/uw436.

\section{Basic Steps to Creating a Land Trust in Your Community Step One-Evaluate the Potential for a Land Trust}

- Assess the feasibility and need for a land trust in your community. Are there existing local or regional land trusts with priorities similar to those of the land trust you are looking to create? Are there potential donors in your community willing to provide initial and ongoing funds? Are there unprotected lands that provide natural, cultural, or recreational value to your community (e.g., forests, historic sites, or freshwater springs)?

1. This document is WEC403, one of a series of the Wildlife Ecology and Conservation Department, UF/IFAS Extension. Original publication date January 2019. Visit the EDIS website at https://edis.ifas.ufl.edu for the currently supported version of this publication.

2. Benjamin W. North, Ph.D. student; Elizabeth Frances Pienaar, assistant professor and Extension specialist, Human Dimensions of Wildlife and Environmental Economics, Department of Wildlife Ecology and Conservation, UF/IFAS Extension, Gainesville, FL 32611; and Jessica D. Sullivan, Extension faculty-agriculture, UF IFAS Extension-Osceola County, Kissimmee, FL 34744.

The Institute of Food and Agricultural Sciences (IFAS) is an Equal Opportunity Institution authorized to provide research, educational information and other services

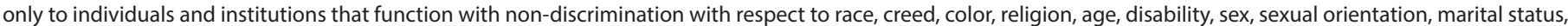

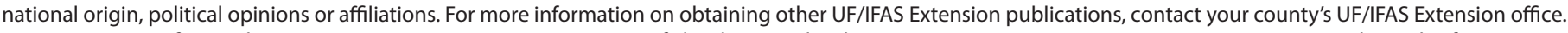
U.S. Department of Agriculture, UF/IFAS Extension Service, University of Florida, IFAS, Florida A \& M University Cooperative Extension Program, and Boards of County Commissioners Cooperating. Nick T. Place, dean for UF/IFAS Extension. 
- Consider the potential mission and functions of your land trust. The more focused the mission and functions of your land trust are, the more effective it will be at achieving its objectives.

- Create a standardized process and criteria for how lands would be evaluated and prioritized for protection (see additional resources below on this topic).

\section{Step Two-Build Community Interest}

- Be prepared to describe how your land trust will offer direct or indirect public benefit by conserving lands important for their natural, cultural, and recreational values.

- Present the idea of creating a land trust to members of your community at local government board meetings, civic organization meetings, or local events.

- Select the board of directors (a minimum of three directors is required in the state of Florida). Carefully choose board members whose interests closely coincide with the mission of your land trust and who are willing to raise funds for the organization.

- Choose a name for your land trust.

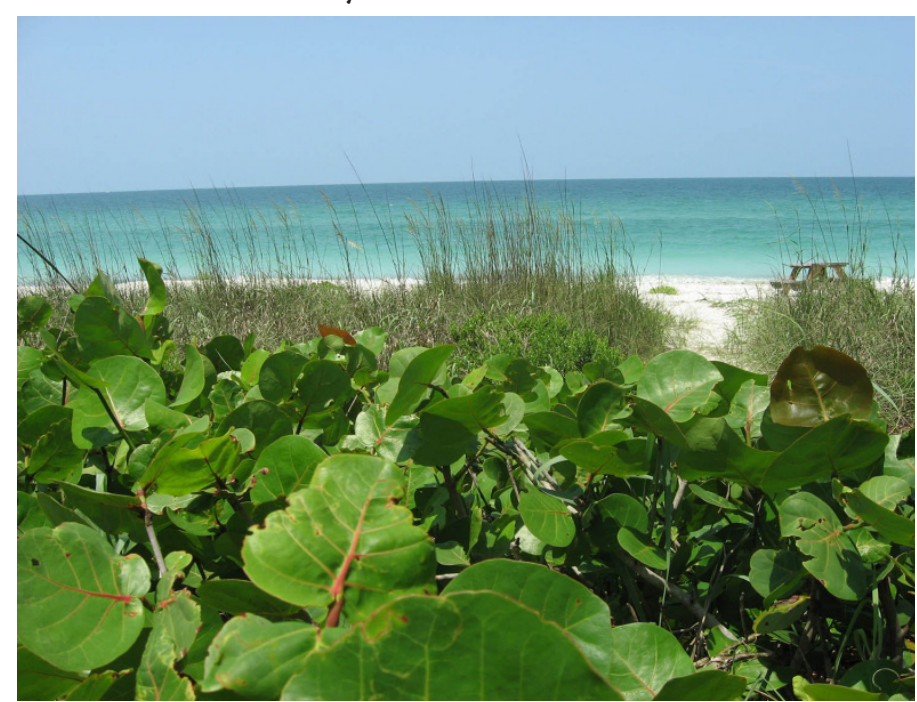

Figure 1. Coastal dunes and beach protected by the Conservation Foundation of the Gulf Coast in Florida.

Credits: Everett Marc, courtesy of Conservation Foundation of the Gul Coast

\section{Step Three-Create Bylaws and Formally Establish Your Land Trust}

- Create bylaws for your land trust. Bylaws are a set of rules to govern and provide organizational structure for your land trust (see additional resources below for an example of bylaws from a land trust).

- Complete the nonprofit articles of incorporation for your organization, and submit this form to the Division of Corporations in the Florida Department of State (see additional resources below for the application).

- Apply for an Employer Identification Number (EIN) with the Internal Revenue Services (IRS) (see additional resources below for the application). Even land trusts that do not hire employees need to apply for an EIN because it is necessary to open a bank account for the organization, apply for 501(c)(3) status, and submit 990 forms to the IRS (financial information forms provided by tax-exempt organizations).

- Consult the Land Trust Alliance's "Land Trust Standards and Practices." The Land Trust Alliance provides a framework for legal and ethical accountability (see additional resources below for this document). If your land trust chooses to adopt these practices, they can also apply for the nationally recognized, voluntary land trust accreditation through the Land Trust Alliance.

\section{Step Four-Apply for Tax Exemptions and Fundraising Approval}

- Apply for approval as a small charitable organization through the Florida Department of Agriculture and Consumer Services to be eligible to conduct fundraising solicitations with Florida residents (see additional resources below for forms). If donations will be accepted from donors in other states, apply for fundraising approval with those states.

- Conservation land trusts are considered 501(c)(3) organizations because they are classified under Section 501(c)(3) of the Internal Revenue Code as nonprofit, tax-exempt charitable organizations. New land trusts must submit IRS form 1023 to receive 501(c) federal tax exemption (see additional resources below for the relevant forms).

- Apply for Florida state sales and use tax exemption (see additional resources below for forms).

\section{Step Five-Expand the Impact of Your Land Trust}

- Encourage involvement from your community through educational and fundraising events and volunteer opportunities.

- Increase funding through private donations, membership fees, corporate sponsorship, and grant funding from government agencies and private foundations. Conduct capital campaigns to meet targeted fundraising goals for your land trust.

- Strongly consider acquiring paid staff to assist with vital tasks that require reliability and consistency, such 


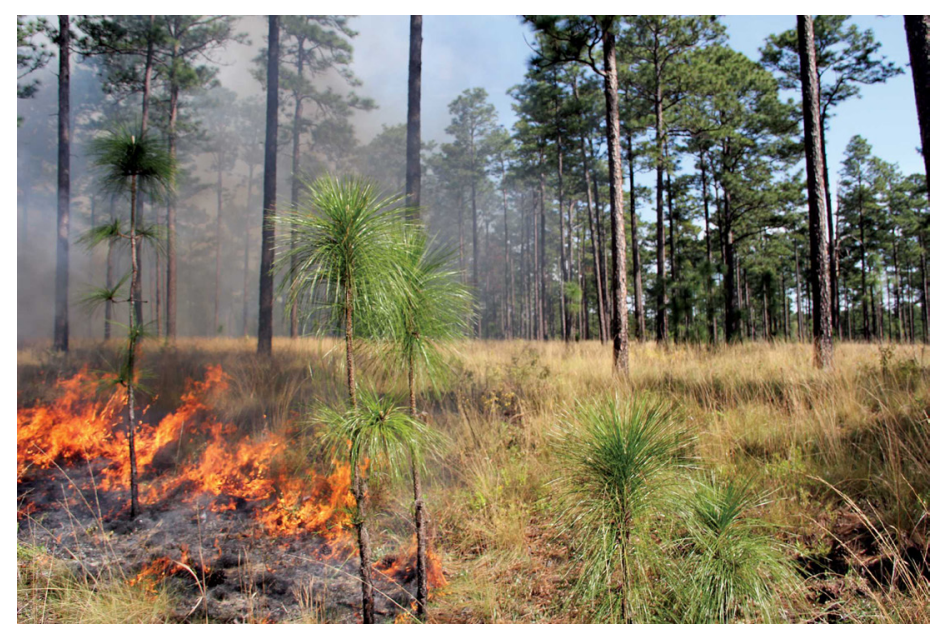

Figure 2. Longleaf pine forest protected by the Tall Timbers Conservancy in Florida.

Credits: Tall Timbers

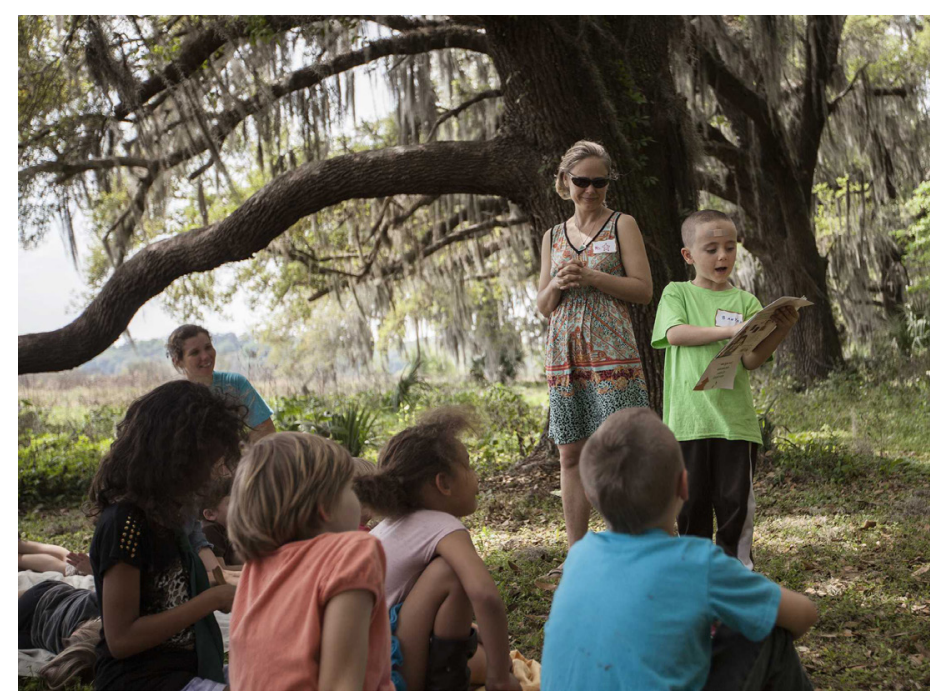

Figure 3. An outdoor education program with Alachua Conservation Trust's Tuscawilla Learning Center on their Tuscawilla Preserve. Credits: Chris Burney

as recordkeeping, fundraising, and land stewardship. Relying solely on volunteer resources can leave a land trust vulnerable to liability issues and limit its growth.

- Research potential contractors or partners who can provide specialized services on demand as needed. Such services may include legal services, appraisal services, geographic information services, graphic design, publicity, accounting, or surveying.

- Form partnerships with surrounding land trusts, local governments, and educational institutions to advance land conservation and stewardship in your community.

- Develop education and outreach initiatives to increase the conservation impact of your land trust in your community.

\section{Resources for Creating a Land Trust in Florida}

Conservation Easements: Options for Preserving Current Land Uses: http://edis.ifas.ufl.edu/fr149

Land Trusts in Florida: A Brief Guide to Land Trusts to Protect Land in Your Community: http://edis.ifas.ufl.edu/ uw436

Evaluating and selecting conservation projects: https://www.landtrustalliance.org/publication/ evaluating-and-selecting-conservation-projects

Instructions for filing Florida state not for profit articles of incorporation: http://form.sunbiz.org/pdf/cr2e006.pdf

Application for Employer Identification Number (EIN) Income Tax Exemption Form 1023: https://www.irs.gov/ pub/irs-pdf/fss4.pdf

Land trust standards and practices: https://www.landtrustalliance.org/topics/land-trust-standards-and-practices

Conservation tools: an online resource available through the Pennsylvania Land Trust Association: https://conservationtools.org/

Federal Income Tax Exemption Form 1023: https://www. irs.gov/forms-pubs/about-form-1023

Florida State Sales and Use Tax Exemption Form: http:// floridarevenue.com/Forms_library/current/dr5.pdf

Small charitable organizations/sponsors application: http://forms.freshfromflorida.com/10110.pdf

Sample bylaws for a land trust: http://massland.org/ library/bylaws-sample-0

Pennsylvania Land Trust Association: https://conserveland.org/conservation-101/

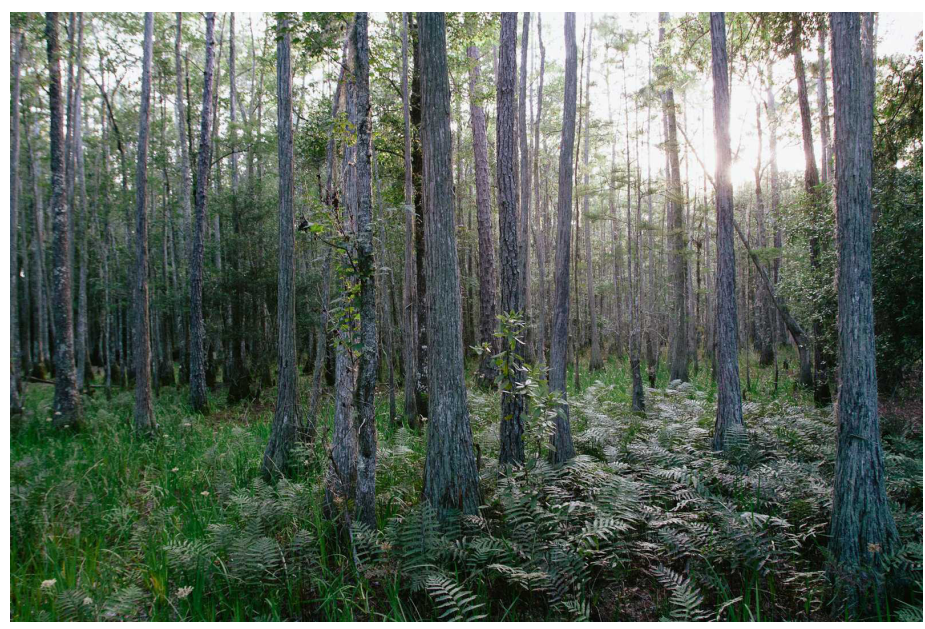

Figure 4. Cypress dome protected by the North Florida Land Trust. Credits: Keith Novosel 


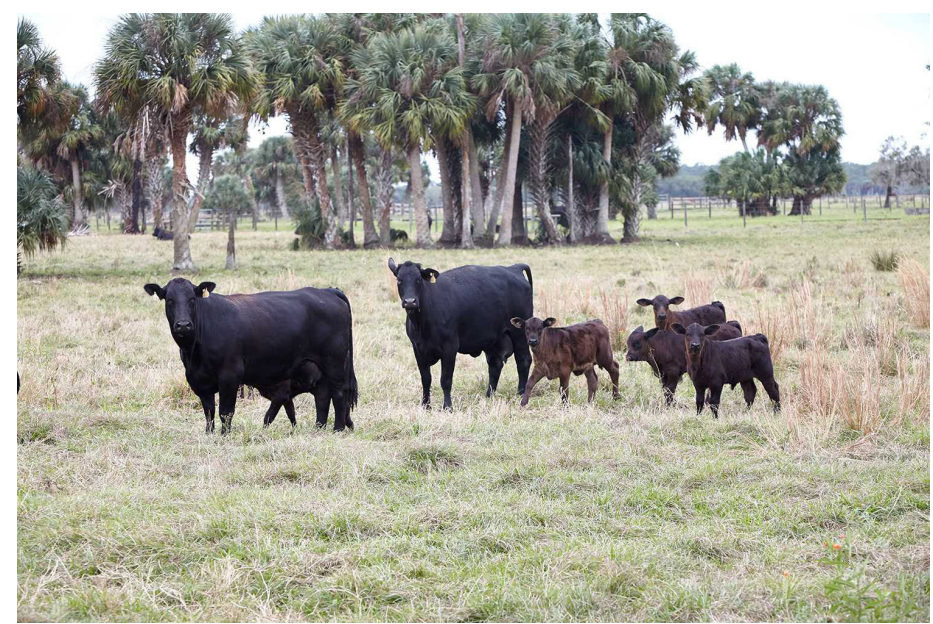

Figure 5. Ranchland protected by the Conservation Trust for Florida in partnership with Pelaez and Sons Ranch.

Credits: Randy Batista

\section{Organizations That Can Help Develop or Fund Land Trust Efforts}

\section{Land Trust Alliance-Southeast Office}

The Land Trust Alliance (LTA) is a national landconservation organization committed to helping land trusts. The LTA's Southeast program focuses on building organizational strength, training land trust personnel, and fostering collaboration.

Website: https://www.landtrustalliance.org/what-we-do/ our-regional-programs/southeast

Email: southeast@lta.org

Phone: 919-827-0284

Address: PO Box 12212 Research Triangle Park, NC 27709

\section{Alliance of Florida Land Trusts}

A statewide network of over 25 environmental, community, and environmental justice organizations.

Phone: 352-373-1078

Address: 7204 SE County Road 234, Gainesville, FL 32641

\section{Edyth Bush Institute for Philanthropy \& Nonprofit Leadership-Rollins College}

The Edyth Bush Institute provides online trainings, consulting services, certificate programs, and custom programs for creating and developing nonprofit organizations.

Website: http://ebi.rollins.edu/

Online Training Course-Steps for Starting a 501(c)(3)

Nonprofit: http://ebi.rollins.edu/?page=Online501c3

Email: ebi@rollins.edu

Address: 200 E New England Ave, Winter Park, FL 32789

\section{Florida Department of Environmental Protection}

The Florida Department of Environmental Protection offers several grant funding opportunities for acquiring and developing land for public and recreational use. These include the Florida Recreation Development Assistance Program, Land and Water Conservation Fund Program, Recreational Trails Program, and the Parks and Open Space Florida Forever Grant Program.

Website: https://floridadep.gov/OOO/

Land-And-Recreation-Grants

Phone: 850-245-2501 (Administrative Support-Land and Recreation Grants Section)

Address: 3900 Commonwealth Blvd, MS550, Tallahassee, FL 32399-3000

\section{USDA Natural Resources Conservation Service}

The USDA NRCS provides matching funds to eligible partner organizations for the purchase of conservation easements on private working lands through their Agricultural Conservation Easement Program (ACEP), which includes Agricultural Land Easements (ALE) and Wetland Reserve Easements (WRE)

Website: https://www.nrcs.usda.gov/wps/portal/nrcs/ main/fl/programs/easements/acep/

Phone: (352)-338-9500

Address: Florida NRCS State Office, 2614 NW 43 ${ }^{\text {rd }}$ St., Gainesville, FL 32606

\section{US Department of Defense}

US DoD helps protect conservation and agricultural lands surrounding military installations and ranges through their Readiness and Environmental Protection Integration (REPI) program.

Website: http://www.repi.mil/

\section{The Trust for Public Land}

The Trust for Public Land helps communities raise funds, conduct research and planning, acquire and protect land, and design and renovate parks, playgrounds, trails, and gardens.

Website: https://www.tpl.org/

Phone: (850) 222-7911

Address: The Trust for Public Land-Florida, $306 \mathrm{~N}$

Monroe Street, Tallahassee, FL 32301 


\section{Florida Forest Service}

The Florida Forest Service implements the US Forest Service's Forest Legacy Program grants and the State of Florida's Rural and Family Lands Protection Program, which protects working agricultural lands.

Website: https://www.freshfromflorida.com/

Phone: (850) 681-5800

Address: Florida Department of Agriculture and

Consumer Services-Florida Forest Service, 3125 Conner

Blvd., Tallahassee, FL 32399

\section{The Nature Conservancy}

TNC works with landowners, communities, and land trusts to help them protect conservation lands.

Website: https://www.nature.org/en-us/

Phone: (407) 682-3664

Address: The Nature Conservancy-Florida, 2500 Maitland

Center Parkway, Suite 311, Maitland, FL 32751

\section{Reference}

Land Trust Alliance. "Why Conserve Land." 2018. Land Trust Alliance Website. Retrieved October 8, 2018 from https://www.landtrustalliance.org/why-conserve-land 